\title{
Penyelesaian Sengketa Merek Terkenal "SEPHORA" atas Dasar Persamaan Pada Pokoknya Berdasarkan Herzien Inlandsch Reglement (HIR) dan Undang-Undang Merek
}

\author{
Sherly Ayuna Putri'; Tasya Safiranita Ramli² Hazar Kusmayanti ${ }^{3}$ \\ 1. Faculty of Law, Padjadjaran University, Indonesia \\ 2. Faculty of Law, Maranatha Christian University, Indonesia \\ 3. Faculty of Law, Padjadjaran University, Indonesia
}

tasya_safiranita@yahoo.com

Submitted: 2017-10-25; Reviewed: 2017-11-23; Accepted: 2017-11-27

\begin{abstract}
Brand is a sign in the form of pictures, names, words of letters, numbers, arrangement of colors, or combinations of those elements which have distinguishthing power and are used in goods or service trade activities. The terms in the brand, especially regarding the protection of famous brands, can actually be applied in the case of domain names. "There is a provision in the TRIPs that governs the issue of protection of this famous brand, and the public becomes bound by the provision because it has been ratified". The meaning is Article 16 (3) TRIPs (Trade Related Aspect of Intellectual Property Rights). Article 16 (3) states that Article 6 bis of the Paris Convention on Protection of Industrial Property Rights shall apply, mutatis mutandis to goods and services which are not similar to goods and services to which a trademark has been registered..
\end{abstract}

Keywords: Distinguishing power; Domain Name; Trade mark; TRIPs.

\section{PENDAHULUAN}

Dalam Pasal 24 Undang - Undang Dasar 1945 dijelaskan bahwa penyelesaian sengketa yang terjadi dikalangan masayarakat dilakukan melaui jalur pengadilan (litigasi). Badan peradilan adalah pemegang kekuasaan kehakiman yang mewujudkan hukum dan keadilan. Meskipun demikian, sistem hukum Indonesia juga membuka peluang menyelesaikan sengketa di luar pengadilan (nonlitigasi). Belakangan ini eksistensi Pengadilan Niaga disorot kuat, antara lain karena terjadi penurunan jumlah perkara yang masuk. Penurunan ini mencemaskan, mengingat Pengadilan Niaga juga ditujukan untuk menyelesaikan masalah lain di bidang perniagaan lainnya. Artinya, sejak awal Pengadilan Niaga dirancang untuk diperluas kompetensinya. Saat ini perluasan kompetensi itu mencakup kewenangan untuk memeriksa 
masalah-masalah yang terkait dengan Kekayaan Intelektual, yang meliputi kewenangan memeriksa sengketa merek, paten, desain industri, dan desain tata letak sirkuit terpadu.Merek pada awalnya hanya berfungsi sebagai alat untuk mengidentifikasi barang dan atau jasa. ${ }^{1}$

Ketika konsumen melihat merek A untuk produk pasta gigi, maka konsumen harus dilindungi dari kebingungan akan adanya merek pasta gigi lainnya yang menyerupai merek A. Oleh karenanya setiap merek harus mempunyai daya pembeda antara satu merek dengan merek yang lainnya sehingga konsumen tidak mengalami kesulitan dalam mengidentifikasi barang dan atau jasa. ${ }^{2}$

Seiring berkembangnya dunia usaha, fungsi merek mengalami perkembangan, ia tidak hanya berfungsi sebagai alat untuk mengidentifikasi barang dan atau jasa melainkan juga memancarkan reputasi dan goodwill yang terdapat dari suatu merek. Ketika seorang mendengar merek A, maka ia tidak hanya mengidentifikasi merek tersebut sebagai merek suatu barang atau jasa melainkan juga reputasi dan goodwill yang terdapat dibalik merek tersebut. ${ }^{3}$

Reputasi dan goodwill tersebut adalah nilai jual (selling power) yang umumnya hanya dimiliki oleh merek terkenal. Merek terkenal mempunyai nilai jual (selling power) yang lebih besar daripada merek biasa pada umumnya. ${ }^{4}$ Merek terkenal

\footnotetext{
${ }^{1}$ Sara Marie Andrzejewski, "Leave Little Guys Alone!: Protecting Small Business From Overly Litigious Corporations And Trademark Infringement Suits", Journal Of Intellectual Property Law, Volume 19, Issue 1, 2011

2 Barton Beebe, "Search and Persuasion in Trademark Law", Michigan Law Review Volume 103, hlm. 2028-2029

3 Mathias Strasser, "The Rational Basis Of Trademark Protection Revisited: Putting The
}

mencerminkan reputasi dan goodwill yang susah payah dibangun oleh pemilik merek. ${ }^{5}$ Pemilik merek terkenal mendapat perluasan perlindungan yaitu pemilik merek terkenal dilindungi tidak hanya pada barang dan atau jasa yang sejenis melainkan diterapkan terhadap pada barang dan atau jasa yang tidak sejenis. Pada praktiknya merek terkenal sering dimanfaatkan tanpa izin oleh pihak lain untuk mencari keuntungan secara pintas atau secara cepat. Sehingga merek terkenal perlu diberikan perlindungan. Selain perlindungan terhadap merek terkenal juga harus diberikan perlindungan terhadap merek biasa.

Namun pengakuan atas keberadaan dan eksistensi Pengadilan Niaga dalam masingmasing Undang - Undang tersebut belum bersifat integratif dan koordinatif. Hal ini antara lain terlihat dari pengaturan prosedur beracara. Hukum acara yang selama ini digunakan dalam pemeriksaan perkara di Pengadilan Niaga masih menggunakan ketentuan Herziene Indonesisch Reglement/Rechtsreglement

Buitengewesten (HIR / R.BG). Pengadilan Niaga adalah Pengadilan Khusus yang berada pada lingkup Peradilan Umum Perkara-perkara yang menjadi kompetensi Pengadilan Niaga diantaranya mengenai Kepailitan dan PKPU, Hak Kekayaan Intelektual, dan Lembaga Penjamin Simpanan. Ketentuan

Dilution Doctrine Into Context", Fordham Intellectual Property, Media And Entertainment Law Journal, Volume 10, Number 2, 2011, hlm. 385

4 Frank I. Schechter, "The Rational Basis of Trademark Protection", Harvard Law Review, Volume 40, 1926, hlm. 819

${ }^{5}$ Wiiliam E. Ridgway, "Revitalizing the Doctrine of Trademark Misuse", Berkeley Technology Law Journal, Volume 21, Issue 4, 2006, hlm. 1558 
Undang-undang Merek dan Indikasi Geografis Nomor 20 Tahun 2016 menggunakan saluran Pengadilan Niaga sebagai lembaga untuk menyelesaikan sengketa merek. Penggunaan Pengadilan Niaga untuk menyelesaikan sengketa Kekayaan Intelektual perkara merek, bertujuan agar pihak-pihak yang bersengketa bisa segera mendapatkan keadilan.

Pelanggaran merek terkenal selain dapat diselesaikan melalui jalur hukum perdata yaitu melalui gugatan perdata di Pengadilan Niaga, dalam Undang-undang Merek dan Indikasi Geografis Nomor 20 Tahun 2016 diatur pula tentang penyelesaian sengketa merek melalui arbitrase dan alternatif penyelesaian sengketa pada Pasal 93 merujuk dari Pasal 83. Cara penyelesaian sengketa melalui arbitrase dan alternatif penyelesaian sengketa diatur dalam Undang-Undang No 30 Tahun 1999. Dalam undang-undang tersebut dikenal beberapa cara penyelesaian sengketa yaitu:
a. Arbitrase
b. Konsultasi
c. Negosiasi
d. Mediasi
e. Konsiliasi, dan
f. Penilaian ahli.

Diantara keenam cara penyelesaian sengketa diluar pengadilan tersebut, hanya penyelesaian sengketa melalui arbitrase yang menghasilkan putusan memaksa yang dijatuhkan oleh pihak ketiga yaitu arbiter atau majelis arbiter. Putusan arbitrase bersifat final dan mempunyai kekuatan hukum tetap dan mengikat para pihak. Putusan arbitrase bersifat final artinya putusan arbitrase merupakan putusan final dan karenanya tidak dapat diajukan banding, kasasi, atau peninjauan kembali. Sedangkan cara penyelesaian lainnya yang termasuk dalam alternatif penyelesaian sengketa, penyelesaiannya diserahkan pada para pihak, sedangkan pihak ketiga hanya memberikan saran dan memfasilitasi perundingan para pihak.

Menurut Undang-Undang Nomor 30 tahun 1999 tentang Arbitrase dan Alternatif Penyelesaian Sengketa, suatu sengketa dapat diselesaikan melalui alternatif penyelesaian sengketa dengan mendasarkan pada itikad baik dengan mengesampingkan penyelesaian secara litigasi di Pengadilan Niaga. Penyelesaian sengketa melalui alternatif penyelesaian sengketa diselesaikan dalam pertemuan langsung oleh para pihak dan hasilnya dituangkan secara tertulis. Apabila para pihak tidak dapat menyelesaikannya, para pihak atas kesepakatan tertulis dapat menyelesaikannya dengan bantuan pihak ketiga. Peran pihak ketiga hanya sekedar mempermudah jalannya perundingan para pihak agar tercapai kesepakatan. Kesepakatan itulah yang mengikat para pihak setelah ditandatangani dan didaftarkan di Pengadilan Niaga. Selain melalui jalur hukum perdata, arbitrase dan alternatif penyelesaian sengketa, penyelesaian pelanggaran hak atas merek dapat dilakukan melalui jalur hukum pidana. Dalam Undang-Undang Merek dan Indikasi Geografis diatur mengenai perbuatan-perbuatan yang dikategorikan sebagai tindak pidana di bidang merek. Perumusan tindak pidana dalam Undangundang Merek dan Indikasi Geografis tersebut pada dasarnya merupakan perlindungan hukum terhadap kepemilikan dan penggunaan merek oleh pemiliknya 
atau pemegang hak merek.

Undang-undang Merek dan Indikasi Geografis tetap memberikan perlindungan terhadap pemilik atau pemegang merek dagang dan/atau jasa terdaftar. Pada saat diberikan sertifikat tanda perlindungan sah adanya, maka pemegang merek dilindungi untuk menggunakan sendiri merek tersebut atau memberikan izin kepada pihak lain untuk menggunakannya. Ketentuan dalam merek, khususnya mengenai perlindungan atas merek terkenal, sebenarnya dapat diaplikasikan dalam kasus domain name. "Ada ketentuan dalam TRIPs yang mengatur masalah perlindungan merek terkenal ini, dan masyarakat menjadi terikat atas ketentuan tersebut karena telah diratifikasi". ${ }^{6}$ Yang dimaksud adalah Pasal 16 (3) TRIPs (Trade Related Aspect of Intellectual Property Rights). Pasal 16 (3) ini menyatakan bahwa Pasal 6 bis Konvensi Paris tentang Perlindungan Hak Kekayaan Industrial harus berlaku, mutatis mutandis kepada barang dan jasa yang tidak serupa dengan barang-barang serta jasa-jasa di mana suatu merek dagang telah didaftarkan.

Pasal ini mensyaratkan bahwa penggunaan merek dagang sehubungan dengan barang atau jasa tersebut akan mengindikasikan suatu hubungan antara barang dan jasa dan pemilik merek dagang serta dengan ketentuan bahwa kepentingan pemilik merek dagang terdaftar akan dirugikan oleh penggunaan tersebut. Masalah perlindungan merek terkenal memang diatur dalam Undang-undang Merek dan Indikasi Geografis. Namun sepanjang pengamatan, kedua Undang- undang ini hanya melindungi merek terkenal dalam rangka pendaftarannya di kantor merek. Sedangkan untuk penggunaannya sebagai domain name, belumlah diatur secara jelas.

Dalam Kasus yang penulis ambil, yaitu berdasarkan Putusan Pengadilan Niaga No.34/Pdt.Sus.Merek/2015/PN.Niaga.Jkt. Pst tentang Pelanggaran Merek Terkenal "Sephora". Bahwa perusahaan Penggugat, Sephora, telah menggunakan Merek "Sephora" sejak tahun 1970 untuk kegiatan usaha yang terkait dengan penjualan kosmetik, pertama kali di Paris, Perancis.

Dari penggunaan Merek "Sephora" secara berkesinambungan di banyak negara di dunia, yang dimulai sejak tahun 1970 tersebut, Penggugat telah berhasil mengembangkan reputasi yang baik terkait dengan penggunaan Merek “Sephora”. Saat ini, Penggugat merupakan penjual dan distributor produk kosmetik, parfum dan barang-barang yang berkaitan dengan kecantikan dan perawatan tubuh, serta erat diasosiasikan dengan jasa kecantikan di seluruh dunia;Adapun contoh penggunaan Merek "Sephora" yang digunakan oleh Penggugat dalam kegiatan usahanya di manca negara hingga saat ini.

Bahwa Penggugat mendaftarkan gugatannya ke Pengadilan Niaga kemudian mengetahui ternyata di dalam Daftar Umum Merek pada Turut Tergugat, telah terdaftar Merek Sephora atas nama Tergugat untuk melindungi produk-produk dalam Kelas 25 dan jasa-jasa di Kelas 35 dengan detail sebagai berikut, yaitu segala macam pakaian yaitu; pakaian jadi, pakaian pria, pakaian wanita, pakaian anak dan

\footnotetext{
${ }^{6}$ Ahmad Ramli, Perlindungan Nama Domain di Indonesia, www.hukumonline.com, diakses tanggal 11 Desember 2016.
} 
bayi, popok bayi dari tekstil, b aju, pakaian tidur, piyama, daster, pakaian dalam, $\mathrm{BH}$, korset, lingerie, celana panjang, celana pendek, celana renang, kulot, jaket, mantel, kemeja, t-shirt, jas, jeans, kaos-kaos, kaos kerah, kaos oblong, kaos tanktop, kaos olahraga, pakaian olahraga, baju renang, pakaian pantai, boa (hiasan leher), blus, gaun, syal, dasi, ikat pinggang (pakaian), sarung tangan, kaos kaki, segala macam alas kaki, sepatu, olahraga, macam tutup kepala, topi, kopiah, peci, pet, dan ikat kepala.

Berdasarkan uraian di atas maka ditemukan permasalahan yaitu Bagaimanakah mekanisme prosedur hukum acara dalam penyelesaian sengketa tentang merek terkenal "SEPHORA" dan pembuktian perkara Hak atas Kekayaan Intelektual di Pengadilan Niaga berdasarkan HIR dan Apakah Putusan Pengadilan Niaga No.34 / Pdt.Sus.Merek / 2015 / PN.Niaga.Jkt.Pst tentang pelanggaran merek terkenal "SEPHORA", telah sesuai dengan prinsip-prinsip hukum merek yang diatur dalam TRIPs dan Undang-undang Nomor 20 tahun 2016 tentang Merek dan Indikasi Geografis. Dalam hal ini yang menjadi keberatan penggugat dikarenakan adanya persamaan pada pokoknya yang digunakan pada merek Sephora yang seharusnya adalah hanya dalam brand kosmetik ternama yang sudah menjadi merek terekenal.

\section{PEMBAHASAN}

\section{Penyelesaian Sengketa Pelanggaran Merek Terkenal}

Atas

Merek adalah tanda yang dapat ditampilkan secara grafis berupa gambar, logo, nama, kata, huruf, angka, susunan warna, dalam bentuk dua dimensi dan/atau tiga dimensi, suara, hologram, atau kombinasi dari dua atau lebih unsur tersebut untuk membedakan barang dan/atau jasa yang diproduksi oleh orang atau badan hukum dalam kegiatan perdagangan barang dan/atau jasa.

Merek dalam dunia kekayaan intelektual sangat erat kaitannya dengan persaingan tidak jujur (unfair competition). Secara umum kompetisi atau persaingan dalam perdagangan adalah baik, sebab dapat meningkatkan kualitas maupun kuantitas suatu produk, memperlancar produksi, yang pada akhirnya akan menguntungkan baik pihak produsen maupun konsumen. Persaingan yang dilakukan dengan cara melawan hukum, norma sopan santun, norma social lain dalam lalu lintas perdagangan akan menjurus pada persaingan curang.

Menurut Molengraaf, persaingan tidak jujur adalah peristiwa di dalam mana seseorang untuk menarik para langganan orang lain kepada perusahaan dirinya sendiri atau demi perluasan penjualan omzet perusahaannya, menggunakan caracara yang bertentangan dengan itikad baik dan kejujuran di dalam perdagangan.

Perdagangan yang meningkat pesat, serta kemajuan perdagangan di era globalisasi memposisikan "pengetahuan dan penemuan" yang kemudian lebih dikenal sebagai intellectual property rights (hak kekayaan intelektual) sebagai unsur yang sangat esensial dalam setiap kegiatan usaha. Kreativitas yang dimiliki para pencipta dan penemu mendorong perkembangan ilmu pengetahuan yang secara langsung maupun tidak langsung akan meningkatkan perekonomian. Didalam memberikan penghargaan serta mendorong kreativitas masyarakat, maka 
karya intelektual yang dihasilkan perlu dilindungi. $^{7}$

Persaingan usaha yang sangat ketat memposisikan beberapa pelaku usaha menjadi market leader (penguasa pasar). Pelaku usaha lain harus berusaha keras untuk dapat menembus pasar yang telah dikuasai oleh pelaku usaha tersebut. Akibatnya, ada kecenderungan para pelaku usaha memanfaatkan ketenaran atau kesuksesan pelaku usaha lain. Jika ini dilakukan secara legal misalnya dengan perjanjian lisensi atau franchise tentunya tidak menjadi persoalan tetapi ada kalanya pelaku usaha menggunakan cara-cara tidak jujur dan mengarah kepada persaingan curang ini dapat dilihat dengan maraknya penjiplakan, pemalsuan atau pembajakan karya intelektual. ${ }^{8}$

Berdasarkan perjanjian TRIPs WTO pengaturan Internasional Kekayaan Intelektual adalah bagian yang tidak dapat dipisahkan dari sistem pengaturan Kekayaan Intelektual di Indonesia. Standar Kekayaan Intelektual Internasional telah menjadi sebuah sumber yang penting bagi hukum yang mengatur tentang Kekayaan Intelektual Indonesia, dan sistem administrasi Internasional memberikan sumbangan kepada sistem administrasi Kekayaan Intelektual di Indonesia. Indonesia juga telah menjadi peserta aktif dalam banyak pengembangan Kekayaan Intelektual saat ini, khususnya melalui keikutsertaannya sebagai negara peserta dalam organisasi perdagangan dunia

\footnotetext{
7 Layla Fitria, "Perkembangan KI dewasa ini", Kompas 23 Juni 2008.

${ }^{8}$ Ibid, Kompas 23 Juni 2008.

9 Mahmud Marzuki, Masalah-masalah Praktis mengenai Hak Kekayaan Intelektual, Makalah disampaikan pada Penataran Hukum Perdata dan Ekonomi di Fakultas Hukum Universitas Gadjah Mada, Yogyakarta 23-30 Agustus 1999.
}

(WTO) dan organisasi Kekayaan Intelektual dunia (WIPO). ${ }^{9}$

Penggunaan merek terkenal ini, sudah cukup memberikan aset yang cukup berharga sebagai pembentuk merek di dunia. Selain itu juga, dalam hal ini dapat memberi manfaat kepada umat manusia sebagai pihak konsumen. Dalam Undangundang Nomor 20 tahun 2016 tentang Merek dan indikasi geografismenerapkan sistem first to file principle ${ }^{10}$, yang artinya hak atas merek diberikan kepada pendaftar lebih awal. Walaupun hal tersebut tidaklah mutlak, karena bagi pendaftar lebih dulu, apabila ia dinyatakan bertentangan dengan peraturan Perundang-undangan yang berlaku, maka pendaftaran itu dapat dibatalkan.

Pembatalan merek terdaftar yang juga diatur dalam Undang-Undang Nomor 20 tahun 2016 tentang Merek, dapat diajukan oleh pihak yang berkepentingan atau pemilik merek terdaftar, baik dalam bentuk permohonan kepada Direktorat Jendral Kekayaan Intelektual maupun gugatan kepada Pengadilan Niaga.

Pengaturan mengenai hal ini dapat dilihat dalam Pasal 21, Pasal 22 dan Pasal 25 Undang-Undang Merek dan Indikasi Geografis. Dimungkinkan bagi pemilik merek terdaftar mempunyai hak untuk mengajukan gugatan perdata di dalam penyelesaian suatu sengketa merek pada Pengadilan Niaga, merupakan suatu konsekuensi dari perlindungan hukum hak atas merek yang diberikan oleh Undang-

\footnotetext{
${ }^{10}$ Apabila dalam penerapan nama domain dikenal istilah first come first served, yaitu pihak yang memiliki nama domain adalah pihak yang mendaftar nama domain tersebut terlebih dahulu. Penerapan ini serupa dengan system merek Indonesia. Untuk lebih jelas lihat Pasal 3 UU Merek.
} 
undang merek dan indikasi geografis. Pemilik merek terdafar mempunyai hak untuk mengajukan gugatan perdata baik berupa ganti rugi jika mereknya dipergunakan pihak lain tanpa seizin darinya, juga penghentian semua perbuatan yang berkaitan dengan penggunaan merek tersebut. Hal ini terdapat pada Pasal 66, Pasal 68 Undang-Undang Merek dan Indikasi Geografis yang berbunyi:

1. Terhadap pelanggaran sebagaimana dimaksud dalam Pasal 66 dapat diajukan gugatan.

2. Gugatan sebagaimana dimaksudd pada ayat (1) dapat dilakukan oleh:

a. setiap produsen yang berhak menggunakan Indikasi

Geografis; dan/atau

b. lembaga yang mewakili masyarakat di kawasan geografis tertentu dan yang diberi kewenangan untuk itu.

Dalam Pasal 68 disebutkan bahwa:

1. Dalam hal sebelum atau pada saat dimohonkan pendaftaran sebagai Indikasi Geografis, suatu tanda dipakai dengan iktikad baik oleh pihak lain yang tidak berhak mendaftar menurut ketentuan sebagaimana dimaksud dalam Pasal 53 ayat (3), pihak yang beriktikad baik tersebut tetap dapat menggunakan tanda tersebut untuk jangka waktu 2 (dua) tahun terhitung sejak tanda tersebut terdaftar sebagai Indikasi Geografis.

2. Dalam hal tanda sebagaimana dimaksud pada ayat (1) telah terdaftar sebagai Merek, Menteri membatalkan dan mencoret pendaftaran Merek tersebut untuk seluruh atau sebagian jenis barang yang sama setelah jangka waktu 2 (dua) tahun terhitung sejak tanda tersebut terdaftar sebagai Indikasi Geografis.

3. Pembatalan dan pencoretan pendaftaran Merek sebagaimana dimaksud pada ayat diberitahukan secara tertulis kepada pemilik Merek atau Kuasanya dengan menyebutkan alasannya.

4. Pembatalan dan pencoretan pendaftaran Merek sebagaimana dimaksud pada ayat (2) dicatat dan diumumkan dalam Berita Resmi Merek.

5. Pembatalan dan pencoretan pendaftaran Merek sebagaimana dimaksud pada ayat mengakibatkan berakhirnya pelindungan hukum atas Merek tersebut untuk seluruh atau sebagian jenis barang yang sama.

6. Keberatan terhadap pembatalan dan pencoretan sebagaimana dimaksud pada ayat (2) dapat diajukan kepada Pengadilan Niaga.

7. Terhadap putusan Pengadilan Niaga sebagaimana dimaksud pada ayat (6) dapat diajukan kasasi.

Di Dalam HIR pengajuan gugatan diatur dalam Pasal 118 ayat (1) HIR pengajuan gugatan perdata di diajukan di Pengadilan Negeri berdasarkan kompetensi relatifnya-berdasarkan tempat tinggal tergugat atau domisisli hukum yang ditunjuk berdasarkan kesepakatan. Gugatan tersebut diajukan secara tertulis yang ditandatangani oleh Penggugat atau 
Kuasanya dan ditunjukan kepada ketua Pengadilan Negeri. Pendaftaran gugatan dapat dilakukan di kantor Kepaniteraan Pengadilan Negeri setempat.

Bahwa dalam Undang-Undang Merek dan Indikasi Geografis terdapat lima macam gugatan yang dikenal yaitu gugatan penghapusan merek, gugatan pembatalan merek, gugatan ganti rugi atas pelanggaran merek terhadap pihak lain yang secara tanpa hak menggunakan merek yang mempunyai persamaan pada pokoknya atau keseluruhannya untuk barang atau jasa yang dimiliki oleh pemilik merek terdaftar, gugatan penghentian semua perbuatan yang berkaitan dengan penggunaan merek oleh pihak lain yang mempunyai persamaan pada pokoknya atau keseluruhannya untuk barang atau jasa yang sejenis oleh pemilik merek terdaftar, dan gugatan atas putusan penolakan permohonan banding oleh Komisi Banding Merek.

\section{PENUTUP}

Di dalam pengaturan Kekayaan Intelektual (KI) merupakan hal yang sulit didefinisikan. Meskipun demikian, uraian mengenai KI dapat digambarkan secara umum. Sebagai contoh, Kekayaan Intelektual dapat melindungi karya sastra dan karya artistik serta invensi dari penggunaan atau peniruan yang dilakukan oleh pihak lain tanpa izin. ${ }^{11}$ Jadi, Kekayaan

\footnotetext{
${ }^{11}$ Tim Lindsey, (et.al), op.cit, hlm. 2.

12 Istilah inipun sejalan dengan pendirian Sudargo Gautama yang tetap konsisten menggunakan istilah Hak Milik Intelektual dan bukan Hak atas Kekayaan Intelektual, lihat, "Konvensi-konvensi Hak Milik Intelektual Baru Untuk Indonesia 1997”, hlm. 1.

${ }^{13}$ Lihat, Abdul Kadir Muhammad, Hukum Harta Kekayaan, Bandung: Citra Aditya Bakti, 1994, hlm. 75, yang menyatakan bahwa: "Menurut ketentuan Pasal 499 KUHPrerdata, pengertian benda meliputi
}

Intelektual pada umumnya berhubungan dengan perlindungan penerapan ide dan informasi yang memiliki nilai komersial. Kekayaan Intelektual adalah kekayaan pribadi yang dapat dimiliki dan diperlakukan sama dengan bentuk-bentuk kekayaan lainnya.

Saat ini terdapat beberapa istilah yang digunakan untuk memberikan pengertian terhadap hak tersebut yang merupakan terjemahan dari Intellectual Property Rights (IPR). Istilah lain yang digunakan untuk terjemahan IPR adalah Hak Milik Intelektual, 12 kata "milik" lebih tepat digunakan daripada kata "kekayaan" karena alasan-alasan bahwa pengertian "hak milik" memiliki ruang lingkup yang lebih luas dan spesifik dibandingkan dengan istilah "kekayaan". Dalam sistem Hukum Perdata Indonesia sendiri hukum harta kekayaan justru terdiri atas dua bagian yaitu hukum perikatan dan hukum benda. ${ }^{13}$ Dalam konsep harta kekayaan setiap barang selalu ada pemiliknya yang disebut pemilik barang dan setiap pemilik barang mempunyai hak atas barang miliknya yang lazim disebut hak milik. ${ }^{14}$

Dari pengertian ini maka istilah "milik" lebih menunjuk kepada hak seseorang atas suatu benda secara konkret dan bukan menunjuk kepada suatu "harta kekayaan" yang sangat luas. Kekayaan Intelektual lebih tepat dikualifikasikan sebagai hak milik karena hak milik itu sendiri

barang fdan hak. Barang adalah benda material yang ada wujudnya karena dapat dilihat dan diraba, dalam bahasa Inggris disebut tangible goods, misalnya kendaraan, komputer, rumah, tanah. Sedangkan hak adalah benda immaterial yang tidak ada wujudnya karena tidak dapat dilihat dan diraba, dalam bahasa Inggris disebut intangible goods, misalnya milik intelektual, gadai, hipotik, piutang, hak pakai, hak pungut hasil, hak guna usaha".

${ }^{14}$ Ibid, hlm 37. 
merupakan hak yang paling utama jika dibandingkan dengan hak-hak kebendaan lainnya, dengan demikian pemilik berhak menikmati dan menguasai dengan sebebasbebasnya.

Kekuasaan kehakiman, dalam konteks negara Indonesia, adalah kekuasaan negara yang merdeka untuk menyelenggarakan peradilan guna menegakkan hukum dan keadilan berdasarkan Pancasila, demi terselenggaranya Negara Hukum Republik Indonesia. Yang dimaksud dengan peradilan adalah tugas yang dibebankan kepada pengadilan. Tugas utama pengadilan adalah sebagai tempat untuk mengadili atau memberikan putusan hukum dalam perkara-perkara yang diajukan kepadanya. Dalam undangundang tentang kekuasaan kehakiman, dibedakan antara peradilan umum dan peradilan khusus. Peradilan umum adalah peradilan bagi rakyat pada umumnya yang menyangkut perkara perdata maupun perkara pidana yang diajukan ke pengadilan.

Penyelesaian sengketa Merek di Pengadilan Niaga diatur dalam UndangUndang Nomor 20 tahun 2016 tentang Merek dan Indikasi Geografis, akan tetapi Undang-Undang Merek ini hanya menjelaskan tentang tata cara gugatan pembatalan pendaftaran merek pada Pasal 76, padahal sengketa yang terdapat dalam ketentuan Undang-Undang Merek tidak hanya masalah gugatan pembatalan merek dan gugatan atas pelanggaran merek saja. Masih ada bentuk sengketa-sengketa merek yang lain misalnya sengketa yang melibatkan Direktorat Merek secara langsung sebagai pihak dalam sengketa merek, yaitu sengketa tentang keberatan atas penolakan perpanjangan jangka waktu perlindungan merek terdaftar atau keberatan terhadap penghapusan merek terdaftar atas prakarsa Direktorat Merek. Pasal 76 Undang- Undang Nomor 20 tahun 2016 tentang Merek dan Indikasi Geografis, sebagai berikut:

1. Gugatan pembatalan Merek terdaftar dapat diajukan oleh pihak yang berkepentingan berdasarkan alasan sebagaimana dimaksud dalam Pasal 20 dan/atau Pasal 21.

2. Pemilik Merek yang tidak terdaftar dapat mengajukan gugatan sebagaimana dimaksud pada ayat (1) setelah mengajukan Permohonan kepada Menteri.

3. Gugatan pembatalan diajukan kepada Pengadilan Niaga terhadap pemilik Merek terdaftar.

Sedangkan dalam Pasal 79 dikatakan bahwa Ketentuan mengenai alasan gugatan pembatalan sebagaimana dimaksud dalam Pasal 76 berlaku secara mutatis mutandis terhadap Merek Kolektif terdaftar. Dalam hal lain dikatakan bahwa, surat permohonan yang didalamnya berisi tuntutan hak perdata oleh suatu pihak yang berkepentingan terhadap suatu hal yang tidak mengandung sengketa, sehingga badan peradilan yang mengadili dapat dianggap suatu proses peradilan yang bukan sebenarnya berdasarkan pasal 120 HIR

\section{DAFTAR PUSTAKA}

\section{Buku}

Abdul Kadir Muhammad, Hukum Harta Kekayaan, Bandung: Citra Aditya Bakti, 1994

Soerjono Soekanto, Pengantar Penelitian Hukum, Jakarta: UI-Press, 1986. 


\section{Jurnal}

tentang Merek dan Indikasi Geografis

Agus Suwandono, Deviana Yuanitasari,

"Kedudukan Lembaga ALternatif

Penyelesaian Sengketa Sektor Jasa

Keuangan Dalam Hukum Perlindungan

Konsumen, Jurnal Bina Mulia Hukum,

Volume 1 nomor 1, September 2016.

Barton Beebe, "Search and Persuasion in

Trademark Law", Michigan Law

Review Volume 103.

Frank I. Schechter, "The Rational Basis of

Trademark Protection", Harvard Law

Review, Volume 40

Mathias Strasser, "The Rational Basis of

Trademark Protection Revisited:

Putting the Dilution Doctrine into

Context", Fordham Intellectual

Property, Media and Entertainment

Law Journal, Volume 10, Number 2,

2011.

Mahmud Marzuki, Masalah-masalah

Praktis mengenai Hak Kekayaan

Intelektual, Yogyakarta 23-30 Agustus 2009.

Sara Marie Andrzejewski, "Leave Little

Guys Alone!: Protecting Small

Business From Overly Litigious

Corporations And Trademark

Infringement Suits", Journal Of

Intellectual Property Law, Volume 19,

Issue 1, 2011

Wiiliam E. Ridgway, "Revitalizing the

Doctrine of Trademark Misuse",

Berkeley Technology Law Journal,

Volume 21, Issue 4, 2006

\section{Rujukan Internet}

www.hukumonline.com

Peraturan Perundang-undangan

Undang-Undang Nomor 20 Tahun 2016 